\title{
Quantitative Assessment of the Number of Escherichia Coli Bacteria and Risk Characterization of Food in Cafeteria of Regional Public Hospital Kendari City
}

\author{
Ismiliani saflia ${ }^{1}$, Anwar Mallongi ${ }^{1}$, Muh. Hatta ${ }^{2}$, Hasanuddin Ishak $^{1}$, Agus Birawida $^{1}$, Yahya \\ Thamrin $^{3}$ \\ ${ }^{1}$ Departement of Environmental Health, Faculty of Public Health, Hasanuddin University, \\ Indonesia \\ ${ }^{2}$ Department of Marine and Fisheries Sciences, Hasanuddin University, Indonesia \\ ${ }^{3}$ Department of Occupational Safety and Health, Hasanuddin University, Indonesia
}

\begin{abstract}
One of the cases of disease originating from food is commonly called foodborne disease which is caused by pathogenic microorganisms or microbes that contaminate food. For this reason, it is necessary to calculate a quantitative microbial risk analysis to see the risk of disease caused by bacteria. This study aims to analyze the quantitative risk of Escherichia coli bacteria in food at the Kendari City Hospital canteen against public health problems. This study used an observational method with a cross sectional approach. This study uses a Quantitative Microbial Risk Assessment (QMRA) approach. The samples in this study were each type of food including rice, vegetables, tofu, chicken and fish as well as tea drinks which were taken by accidental sampling. The results showed that the number of Escherichia coli bacteria in the morning food on the first, second and third day was found in tofu, vegetables, chicken at 3.6 CFU / $\mathrm{g}$ and in drinks $3 \mathrm{CFU} / \mathrm{ml}$. The number of Escherichia coli bacteria during the day on the first day was found in vegetables at $6.1 \mathrm{CFU} / \mathrm{g}$, on the second day on vegetables was 9.2 CFU / g, and on the third day in chickens was $14 \mathrm{CFU} / \mathrm{g}$. Characterization of bacterial risk in respondents due to consumption of food in the morning and during the day, shows that Pill $=3.5 \times 10-1$ which means that food samples positive for Escherichia coli bacteria have a high risk of causing health problems in humans such as diarrhea and disorders other health.
\end{abstract}

Keywords: QMRA, Escherichia Coli, Risk Characterization, Diarrhea

Received : October 28, 2020

Received in Revised: November 9, 2020

Accepted: November 13, 2020

\section{Introduction}

Food is all substances that are needed by the body except medicines, water, and other substances used in medicine. One of the cases of disease originating from food is commonly called foodborne disease which is caused by pathogenic microorganisms or microbes that contaminate food (WHO, 2010). In the United States it is reported by The Centers for Disease Control and Prevention (CDC) that there are 31 types of foodborne pathogens that cause about 9.4 million diseases, 56,000 people are hospitalized, and 1,300 deaths each year. Of these 31 well-known pathogens, Escherichia coli is the type of bacteria most studied in a model for understanding bacterial behavior (Xu et al., 2016).

Escherichia coli is found in a wide variety of contaminated plant and animal foods. These foodborne illnesses by bacteria can be in the form of intoxification or infection. Intoxification through food is caused by the presence of bacterial toxins that are formed in food when the 
bacteria multiply, while infection through food is caused by the entry of bacteria into the body through contaminated food and the body reacts to these bacteria (Arlita et al., 2014).

The most common diseases occur due to eating foods that have been contaminated with pathogens such as diarrhea, gastroenteritis, and various other foodborne diseases (Malcolm et al., 2018). Basic sanitation factors and personal hygiene behavior, food sanitation is a trigger factor but also a key factor in controlling diarrhea disease.

Food sanitation is one of the important things to pay attention to, both in restaurants, school canteens, restaurants and hospital canteens. Apart from containing nutritional value, food is also a medium for microbes or germs to breed due to contamination from various sources that can cause health problems such as diarrhea (Sofiana, 2012). In a study conducted by Inggit Saridewi et al (2016) who examined the presence of bacteria in ready-to-eat food in the X Hospital canteen, which showed that there was an indication of bacteria found in the food samples tested which, if consumed, could cause health problems. Another study was also conducted by Kiermeier et al (2015) who examined E. coli bacteria in fast food with the results of the study showing that $\mathrm{E}$. coli was found in consumed meat with a prevalence of 49.6 incidence of disease caused by these bacteria. The existence of foodborne diseases found in food caused by the Escherichia coli bacteria, the researchers carried out a quantitative microbial risk analysis calculation to see the risk of disease caused by these pathogenic bacteria in food consumed in the canteen.

\section{Methods}

This study used an observational method with a cross sectional approach. This study uses a Quantitative Microbial Risk Assessment (QMRA) approach. This research will be carried out in August-September 2020 at the Kendari City Hospital canteen. The population in this study were the canteen at the Kendari City Hospital and visitors who ate food in the canteen at the time of data collection. The sample in this study was each type of food including rice, vegetables, tofu, chicken, fish and tea drinks.

Sources of data used in this study were obtained by conducting interviews using a questionnaire, observation using observation sheets on the respondents. Measurement of food samples and identification of the presence and number of Escherichia coli bacteria were carried out at the Microbiology Laboratory of the Faculty of Medicine, University of Halu Oleo. The data that has been collected regarding the amount of bacterial concentration and the respondents' interviews will be analyzed descriptively and written in a frequency distribution table then narrated.

\section{Results and Discussion}

Table 1. Number of Colonies and Types of Bacteria Using Lactose Broth (Lb) Media Samples of Morning Food on the First, Second, and Third Days at the Kendari City Hospital Canteen 2020

\begin{tabular}{|l|l|l|}
\hline \multicolumn{1}{|c|}{ Sample } & \multicolumn{1}{c|}{$\begin{array}{c}\text { Number of } \\
\text { Colonies (CFU) }\end{array}$} & \multicolumn{1}{|c|}{ Types of Bacteria } \\
\hline First Day & & \\
\hline Chicken & 0 & - \\
\hline Tofu & 3 & Escherichia coli \\
\hline Vegetable & 3,6 & Escherichia coli \\
\hline Tea & $\mathbf{0}$ & - \\
\hline
\end{tabular}




\begin{tabular}{|l|l|l|}
\hline Rice & 0 & - \\
\hline Fish & 0 & - \\
\hline Second Day & & \\
\hline Chicken & 0 & - \\
\hline Tofu & 3,6 & Escherichia coli \\
\hline Vegetables & 3 & Escherichia coli \\
\hline Tea & 3,6 & Escherichia coli \\
\hline Rice & 0 & - \\
\hline Fish & 0 & - \\
\hline Hari Ketiga & & \\
\hline Chicken & 3,6 & Escherichia coli \\
\hline Tofu & 3,6 & Escherichia coli \\
\hline Vegetables & 0 & - \\
\hline Tea & $\mathbf{0}$ & - \\
\hline Rice & 0 & - \\
\hline Fish & 0 & - \\
\hline
\end{tabular}

Table 1 shows that the number of colonies and types of bacteria using the lactose broth (lb) medium of morning food samples on the first, second, and third days in the rsud canteen in Kendari City with the results of the presence of Escherichia coli bacteria on the first day of samples were found mostly in vegetables with a value of $3,6 \mathrm{CFU}$, on the second day the most samples were found in tofu as much as 3.6 CFU and on the third day the most samples found in tofu and chicken were 3.6 CFU.

Table 2. Number of Colonies and Types of Bacteria Using Lactose Broth (Lb) Media Samples of Lunch on the First, Second, and Third Days at the Kendari City Hospital Canteen in 2020

\begin{tabular}{|c|c|c|}
\hline Sample & $\begin{array}{c}\text { Number of Colonies } \\
\text { (CFU) }\end{array}$ & Types of Bacteria \\
\hline First Day & 0 & \\
\hline Chicken & 0 & - \\
\hline Tofu & 3 & Escherichia coli \\
\hline Vegetables & 6,1 & Escherichia coli \\
\hline Tea & $\mathbf{0}$ & - \\
\hline Rice & 0 & - \\
\hline Fish & 0 & - \\
\hline Second Day & & \\
\hline Chicken & 0 & - \\
\hline Tofu & 0 & Escherichia coli \\
\hline Vegetables & 9,2 & Escherichia coli \\
\hline Tea & $\mathbf{0}$ & Escherichia coli \\
\hline Rice & 0 & - \\
\hline Fish & 0 & - \\
\hline Third Day & & \\
\hline
\end{tabular}




\begin{tabular}{|l|c|c|}
\hline Chicken & 14 & Escherichia coli \\
\hline Tofu & 3,6 & Escherichia coli \\
\hline Vegetables & 6,2 & - \\
\hline Tea & 7,4 & - \\
\hline Rice & 0 & - \\
\hline Fish & 0 & - \\
\hline
\end{tabular}

Table 2 shows that the number of colonies and types of bacteria using the lactose broth (lb) media sample of lunch on the first, second, and third days in the Kendari city rsud canteen with the results of the presence of Escherichia coli bacteria on the first day of samples were mostly found in vegetables with a value of $6,1 \mathrm{CFU}$, on the second day the most samples were found in vegetables as much as $9.2 \mathrm{CFU}$ and on the third day the most samples were found in chickens as many as $14 \mathrm{CFU}$.

Table 3. Risk Characterization of Escherichia Coli Bacteria in Respondents Due to Consumption of Morning and Afternoon Food in the Rsud Canteen, Kendari City, 2020

\begin{tabular}{|l|l|l|l|}
\hline \multicolumn{1}{|c|}{ Name } & \multicolumn{1}{|c|}{ Sample } & $\begin{array}{c}\text { Pisk } \\
\text { Escherichia coli }\end{array}$ & $\begin{array}{c}\text { Bacteria } \\
\text { Characterization } \\
\text { Escherichia coli } \\
\text { Bacteria }\end{array}$ \\
\hline AA & Vegetables \& Tofu & $3,5 \times 10^{-1}$ & High Risk \\
\hline AI & Vegetables & $3,5 \times 10^{-2}$ & High Risk \\
\hline BU & Vegetables & $3,5 \times 10^{-3}$ & High Risk \\
\hline AL & Vegetables \& Tofu & $3,5 \times 10^{-4}$ & High Risk \\
\hline AS & Tofu & $3,5 \times 10^{-5}$ & High Risk \\
\hline DH & Vegetables, tea & $3,5 \times 10^{-6}$ & High Risk \\
\hline FA & Vegetables & $3,5 \times 10^{-7}$ & High Risk \\
\hline DI & Tofu \& Vegetables & $3,5 \times 10^{-8}$ & High Risk \\
\hline HW & Vegetables \& Tofu & $3,5 \times 10^{-9}$ & High Risk \\
\hline FH & Tofu & $3,5 \times 10^{-10}$ & High Risk \\
\hline II & Vegetables \& Tofu & $3,5 \times 10^{-11}$ & High Risk \\
\hline IM & Tofu \& tea & $3,5 \times 10^{-12}$ & High Risk \\
\hline KI & Vegetables \& Tofu & $3,5 \times 10^{-13}$ & High Risk \\
\hline RA & Vegetables & $3,5 \times 10^{-14}$ & High Risk \\
\hline RN & Tofu & $3,5 \times 10^{-15}$ & High Risk \\
\hline RU & Vegetables & $3,5 \times 10^{-16}$ & High Risk \\
\hline SA & Vegetables & $3,5 \times 10^{-17}$ & High Risk \\
\hline DG & Vegetables \& tea & High Risk \\
\hline SI & Vegetables & High Risk \\
\hline SR & Tea & High Risk \\
\hline
\end{tabular}




\begin{tabular}{|l|l|l|l|}
\hline WD & Vegetables & $3,5 \times 10^{-21}$ & High Risk \\
\hline ZF & Tofu & $3,5 \times 10^{-22}$ & High Risk \\
\hline SI & Chicken \& Tofu & $3,5 \times 10^{-23}$ & High Risk \\
\hline WU & Chicken & $3,5 \times 10^{-24}$ & High Risk \\
\hline BU & Tofu & $3,5 \times 10^{-25}$ & High Risk \\
\hline IM & Chicken, Vegetables \& tea & $3,5 \times 10^{-26}$ & High Risk \\
\hline DW & Tofu \& Vegetables & $3,5 \times 10^{-27}$ & High Risk \\
\hline IF & Chicken & $3,5 \times 10^{-28}$ & High Risk \\
\hline US & Tofu & $3,5 \times 10^{-29}$ & High Risk \\
\hline DD & Vegetables \& Tea & $3,5 \times 10^{-30}$ & High Risk \\
\hline IK & Chicken \& Tofu & $3,5 \times 10^{-31}$ & High Risk \\
\hline
\end{tabular}

Table 3 shows that the risk characterization of escherichia coli bacteria in respondents due to food consumption in the morning and during the day at the Kendari City Hospital canteen with the results of all respondents who consumed the type of food / drink, namely chicken, vegetables, tofu, and tea with a value of $3.5 \times 10^{-1}$ means having a high risk of developing gastrointestinal disorders and other diseases and the risk of death if consumed continuously.

The presence of bacteria after a biochemical test, there were 4 types of samples that were positive for Escherichia coli, namely tofu, chicken, vegetables and tea drinks. The morning food sample on the first day with the highest number of bacteria was a vegetable sample of 3.6 CFU / g. Meanwhile, the least number of bacteria found in the tofu sample was $3 \mathrm{CFU} /$ g. Meanwhile, for food / drink samples in the morning on the second day, the number of bacteria that was mostly found in tofu was 3.6 CFU / $\mathrm{g}$ and the least number of bacteria found in vegetables was $3 \mathrm{CFU} / \mathrm{g}$. Also, the samples in the morning meal on the third day with the highest number of bacteria were chicken and tofu samples as much as $3.6 \mathrm{CFU} / \mathrm{g}$. When compared with the standards of the NSW Food Authority (2009), this value is still safe for consumption. However, if consumed continuously it may have risks to health. The maximum limit of Esherichia coli contamination in unsafe food is $\geq 100 \mathrm{CFU} / \mathrm{g}$ or $\geq 100 \mathrm{CFU} / \mathrm{ml}$.

The presence of bacteria in the lunch sample had the highest number of bacteria, namely the vegetable sample as much as $6.1 \mathrm{CFU} / \mathrm{g}$. While the lowest number of bacteria was found in the tofu sample as much as $3 \mathrm{CFU} / \mathrm{g}$ and in the drink sample the number of bacteria found was $3 \mathrm{Cfu} / \mathrm{ml}$. Meanwhile, for the lunch sample on the second day, the number of bacteria found in vegetables was 9.2 CFU / $\mathrm{g}$ and the number of bacteria in the drink sample was 3 $\mathrm{CFU} / \mathrm{ml}$. Also, the lunch sample on the third day with the highest number of bacteria was a chicken sample of $14 \mathrm{CFU} / \mathrm{g}$. Meanwhile, the lowest number of bacteria was found in the tofu sample as much as 3.6 CFU / g. and in the drink sample the number of bacteria was 7.4 $\mathrm{CFU} / \mathrm{ml}$.

According to the Food and Drug Supervisory Agency Regulation No.13 of 2019, the maximum limit of microbial contamination in food, the amount of Esherichia coli, is 3 CFU / $\mathrm{g}$, which means that food in the canteen during the day is unsafe if consumed continuously it can pose a health risk.

Analysis of the risk characterization of escherichia coli bacteria in respondents due to food consumption in the morning and during the day, the value obtained from the calculation 
shows that Pill $=3.5 \times 10^{-1}$ which means that food samples that are positive for Escherichia coli bacteria have a high risk of causing health problems in humans such as diarrhea and other health problems. This study is similar to that conducted by Chang et.al (2015) concerning the risk of Escherichia coli bacteria in vegetables and chicken meat with the result that the risk of disease is $5.2 \times 10^{-2}$ in vegetables, and in chickens is $4 \times 10^{-1}$. In addition, a similar study was also conducted by Duffy \& O'Reilly (2016) which showed that the risk of gastrointestinal disorders due to eating meat was $6.4 \times 10^{-4}$ and the risk of death was $7.72 \mathrm{x}$ $10^{-6}$. Furthermore, the same research was also conducted by Lin Sain et.al (2018) regarding the risk of disease in the presence of Escherichia coli in packaged tea drinks, namely $6 \times 10^{-5}$. The same research was also conducted by Chiraporn et.al (2016), on tofu food with a large risk of disease due to Escherichia coli, namely $2.8 \times 10^{-1}$.

\section{Conclusion}

The presence of Escherichia coli on the first day of sample was mostly found in vegetables, namely 3.6 CFU, the second day was mostly found in tofu, namely 3.6 CFU and the third day was mostly found in tofu as much as 3.6 CFU. Samples for lunch, the first day was mostly found in vegetables with a value of $6.1 \mathrm{CFU}$, the second day the most samples were found in vegetables, namely 9.2 CFU and the third day the most were found in chickens, $14 \mathrm{CFU}$ and risk characterization of escherichia coli bacteria in respondents due to consumption of food in the morning and during the day in the canteen, the results of all respondents who consumed food, namely chicken, vegetables, tofu, and tea drinks with a value of $3.5 \times 10^{-1}$ means that they have a high risk.

\section{References}

Ananchaipattana, C., Hosotani, Y., Kawasaki, S., Pongswat, S., Latiful, B. M., Isobe, S., \& Inatsu, Y. (2012). Bacterial contamination of soybean curd (tofu) sold in Thailand. Food Science and Technology Research, 18(6), 843-848.

Arlita, Y. (2014). Identifikasi Bakteri Escherichia Coli Dan Salmonella SP. Pada Makanan Jajanan Bakso Tusuk Di Kota Manado. eBiomedik, 2(1).

Chang, W. S., Afsah-Hejri, L., Rukayadi, Y., Khatib, A., Lye, Y. L., Loo, Y. Y., \& John, Y. H. T. (2013). Quantification of Escherichia coli O157: H7 in organic vegetables and chickens. International Food Research Journal, 20(2).

Duffy, L., \& O'Reilly, S. C. (2016). Toll-like receptors in the pathogenesis of autoimmune diseases: recent and emerging translational developments. ImmunoTargets and therapy, 5, 69 .

Kiermeier, A., Jenson, I., \& Sumner, J. (2015). Risk assessment of Escherichia coli O157 illness from consumption of hamburgers in the United States made from Australian manufacturing beef. Risk Analysis, 35(1), 77-89.

Malcolm, T. T. H., San Chang, W., Loo, Y. Y., Cheah, Y. K., Radzi, C. W. J. W. M., Kantilal, H. K., ... \& Son, R. (2018). Simulation of improper food hygiene practices: a quantitative assessment of Vibrio parahaemolyticus distribution. International journal of food microbiology, 284, 112-119.

Sain, B., \& Murray, N. E. (1980). The hsd (host specificity) genes of E. coli K12. Molecular and General Genetics MGG, 180(1), 35-46. 
Saridewi, I., Pambudi, A., \& Ningrum, Y. F. (2016). Analisis bakteri Escherichia coli pada makanan siap saji di kantin rumah sakit X dan kantin rumah sakit Y. Bioma, 12(2), 90-103.

Sofiana, E. (2012). Hubungan Higiene Dan Sanitasi Dengan Kontaminasi Escherichia Coli Pada Jajanan Di Sekolah Dasar Kecamatan Tapos Depok Tahun 2012. Skripsi, Fakultas Kesehatan Masyarakat Program Studi Kesehatan Masyarakat. Depok: Universitas Indonesia.

WHO. (2010). Foodborne Disease: A focus for health education, Geneva. https://apps.who.int/iris/handle/10665/42428

Xu, M., Wang, R., \& Li, Y. (2016). Rapid detection of Escherichia coli O157: H7 and Salmonella Typhimurium in foods using an electrochemical immunosensor based on screen-printed interdigitated microelectrode and immunomagnetic separation. Talanta, 148, 200-208. 